\title{
AL JAM'IYATUL WASHLIYAH DAN PELESTARIAN AKIDAH AHL SUNNAH WA AL-JAMĀ'AH DI INDONESIA
}

\author{
Ja'far \\ Universitas Islam Negeri Sumatera Utara Medan \\ E-mail: jafar@uinsu.ac.id
}

\begin{abstract}
The development of Islam in Indonesia cannot be separated from the role and influence of Islamic organizations. Islamic organizations in this region are usually divided into two; traditionalist and modernist. One of the Islamic organizations labeled as traditionalists is Al Jam'iyatul Washliyah. Studies on Al Washliyah have been carried out, but the research on the role of $\mathrm{Al}$ Washliyah in developing the Abl al-Sunnah wa al-Jamáab school has not been carried out and is still neglected. This article aims to examine the role of the Al Washliyah organization in strengthening the Abl al-Sunnab wa alJamáa $a b$ school in Indonesia. By combining library and field studies, this study found that Al Washliyah played an active role in developing the thought of the school through its institution called the Al Washliyah Fatwa Council, while the scholars of Al Washliyah had produced works in theology in line with framework of Abl al-Sunnah wa al-Jamäah.
\end{abstract}

Keywords: Al Washliyah; Islamic theology; Abl al-Sunnah wa al-Jamāah.

\section{Pendahuluan}

Deliar Noer ${ }^{1}$ menyebutkan bahwa gerakan-gerakan Islam di awal abad ke-20 bisa dibagi menjadi dua kubu: kaum tua yang disebut Islam tradisionalis dan kaum muda yang disebut kaum modernis. Nahdlatul Ulama (NU), ${ }^{2}$ Persatuan Tarbiyah Islamiyah

1 Deliar Noer, Gerakan Modern Islam di Indonesia 1900-1942 (Jakarta: LP3ES, 1980), vii dan 8 .

2 Paham keagamaan, dalam bentuk fatwa, NU terkini dapat dilihat dalam Achmad Kemal Riza, "Contemporary Fatawa of Nahdlatul Ulama: Between 
(Perti) dan Al Jam'iyatul Washliyah (disingkat Al Washliyah) dikategorikan sebagai kaum tua atau golongan Islam tradisionalis. Sedangkan Muhammadiyah, ${ }^{3}$ Persatuan Islam (Persis), dan Sarekat Islam disebut kaum muda atau golongan Islam modernis. Kelompok pertama, kaum tua, memegang teguh pemikiran dan praktik tradisional, sedangkan kelompok kedua, kaum muda, menginginkan pembaharuan. Kedua kelompok saling bertikai terkait persoalan khilafiah dalam Islam, terutama masalah 'ubüdìyah, dan masalah takhayul, bid'ah dan khurafat, bahkan masalah ini, meskipun mulai diredam oleh kelompok masing-masing, masih muncul sampai pascakemerdekaan. Pertikaian kedua kelompok ini memang masih berada pada level cabang agama (furū' al-dinn), tidak sampai pada masalah pokok agama (usül al-dìn). Kedua kelompok, meskipun kaum tua mempertahankan tradisi ulama klasik, sedangkan kaum muda menginginkan pembaharuan, masih dalam satu ikatan mazhab Sunnī, Abl al-Sunnah wa al-Jamāab yang membedakan mereka dengan gerakan Islam transnasional semacam Shī'ah dan Ahmadiyah.

Golongan Islam tradisi seperti NU, ${ }^{4}$ Perti dan Al Washliyah merupakan organisasi masyarakat Islam yang menganut mazhab Sunnī. Bruinessen menyebut bahwa tujuan NU adalah mengembangkan ajaran Islam menurut mazhab Abl al-Sunnab wa al-Jamäah dan memproteksinya dari penyimpangan golongan modernis. ${ }^{5}$ Koto menyimpulkan bahwa Perti merupakan penganut setia mazhab Abl al-Sunnab wa al-Jamäab. ${ }^{6}$ Ormas Islam lain juga

Observing the Mazhab and Adapting the Context", dalam Journal of Indonesian Islam, Vol. 5, No. 1 (2011), 35-63.

3 Azyumardi Azra, "Muhammadiyah: A Preliminary Study", Studia Islamika, Vol. 1, No. 2 (1994), 89-117.

${ }^{4}$ Kajian tentang teologi NU, lihat Suis Qa'im, "Genealogi Teologi Nahdlatul Ulama”, ISLAMICA: Jurnal Studi Keislaman, Vol. 6, No. 2 (2012), 361-374; Achmad Muhibin Zuhri, "Particular Sunnism Versi Hasyim Asyari tentang Ahl al-Sunnah wa al-Jamā'ah", dalam ISLAMICA: Jurnal Studi Keislaman, Vol. 5, No. 2 (2011), 278-293. Perbandingan antara paham moderat NU dan Muhammadiyah, lihat Toto Suharto, "Gagasan Pendidikan Muhammadiyah dan NU sebagai Potret Pendidikan Islam Moderat di Indonesia", ISLAMICA: Jurnal Studi Keislaman, No. 9, No. 1 (2014), 81-109.

5 Martin van Bruinessen, NU: Tradisi, Relasi-relasi Kuasa, Pencarian Wacana Baru (Yogyakarta: LKiS, 1994), 42.

6 Alaiddin Koto, Persatuan Tarbiyah Islamiyah: Sejarah, Paham Keagamaan dan Pemikiran Politik 1945-1970 (Jakarta: Rajawali Press, 2012), 78. 
sebenarnya menganut mazhab yang sama. Di luar Jawa, ada dua organisasi Islam Sunnī yang didirikan oleh kaum Islam sebelum kemerdekaan Indonesia, yaitu Al Jam'iyatul Washliyah yang didirikan oleh para pelajar Mandailing, ${ }^{7}$ dan Al-Ittihadiyah yang diinisiasi oleh ulama dan tokoh Melayu. ${ }^{8}$ Kedua organisasi Islam yang lahir dan berkembang di Sumatera Utara ini menganut paham Abl al-Sunnah wa al-Jamāab, ${ }^{-}$dan bersama organisasi masyarakat Islam lain menancapkan pengaruh masing-masing.

Untuk kasus Al Washliyah, sejak awal organisasi Islam ini menganut mazhab Shāfiīiyah dan Ahl al-Sunnah wa al-Jamäah. Sebagai pelestari tradisi Sunnī, organisasi Islam ini mendedikasikan potensinya untuk mengembangkan bidang pendidikan, dakwah, dan amal sosial (belakangan ditambah satu bidang lagi yaitu pemberdayaan ekonomi umat). Sebagaimana banyak organisasi Islam lain, Al Washliyah merupakan organisasi yang berasaskan Islam, tetapi dalam bidang fiqh menganut mazhab Shāfíi i. Memang, pada tahun 1997, Al Washliyah tidak lagi hanya menganut satu mazhab, tetapi mengutamakan mazhab Shāfíìah dan mengakomodir mazhab fiqh lain dalam tradisi Sunnī, Namun pada tahun 2015, Al Washliyah kembali hanya setia kepada satu mazhab, Shāfíìah. Dalam bidang akidah, Al Washliyah menganut mazhab Abl al-Sunnah wa al-Jamäáah. Melalui amal usaha yang dimiliki, Al Washliyah turut melestarikan kedua mazhab tersebut di Nusantara.

Para peneliti telah melakukan sejumlah riset tentang $\mathrm{Al}$ Washliyah. Mereka sejauh ini masih terlalu memfokuskan kerja

${ }^{7}$ Chalidjah Hasanuddin, Al Jam'iyatul Washliyah 1930-1942: Api dalam Sekam di Sumatera Timur (Bandung: Pustaka, 1988), 34-40.

8 Mengenai organisasi Al-Ittihadiyah, lihat Dja'far Siddik dan Ja'far, AlIttihadiyah: Delapan Dasawarsa Menerangi Nusantara (Medan: Perdana Publishing, 2017), atau Al Rasyidin, "Organisasi Islam di Tanah Melayu: Ideologi dan Gerakan Al-Ittihadiyah Sebelum Era Reformasi", dalam Journal of Contemporary Islam and Muslim Societies, Vol. 2, No. 1 (2018). Mengenai peran ormas-ormas Islam di Sumatera Utara, khususnya Al Washliyah, Al-Ittihadiyah, Muhammadiyah dan NU, lihat lebih lanjut dalam Al Rasyidin, "Islamic Organizations in North Sumatra: The Politics of Initial Establishment and Later Development", dalam Journal of Indonesian Islam, Vol. 10, No. 1 (2016), 63-88.

9 Paham Al-Ittihadiyah bisa dilihat dalam pandangan ulama-ulamanya, lihat misalnya dalam kajian M. Jamil dan Ja'far, "Pemimpin Perempuan dan NonMuslim Perspektif Ulama Tiga Serangkai", TEOSOFI: Jurnal Tasawuf dan Pemikiran Islam, Vol. 8, No. 1 (2018), 144-167. 
akademik mereka untuk mengamati dan menganalisa amal usaha organisasi ini terutama dalam bidang pendidikan yang terbilang banyak secara kuantitatif. Penelitian terhadap peran Al Washliyah dalam bidang dakwah dan amal sosial juga sudah dilakukan sebagaimana perannya dalam bidang hukum Islam di Indonesia. Belakangan ini, studi tentang relasi antara $\mathrm{Al}$ Washliyah dan politik telah mulai dilakukan segelintir peneliti meskipun tidak komprehensif. Tetapi jelas, dalam konteks akidah, bahwa belum ada peneliti yang mengkaji dimensi teologis yang diyakini, dikembangkan dan dilestarikan oleh Al Washliyah selama ini. Sebab itulah, artikel ini diharapkan dapat mengisi kekosongan riset terkait teologi Al Washliyah.

Lewat studi kepustakaan yang didukung oleh studi lapangan secara terbatas, artikel ini menelaah peran Al Washliyah dalam mengembangkan mazhab Abl al-Sunnah wa al-Jamäab di Indonesia. Secara khusus, artikel ini membahas alasan Al Washliyah menganut mazhab Abl al-Sunnah wa al-Jamā'ah, geneologi dan peran ulama serta lembaga pendidikannya dalam merevitalisasi tradisi mazhab ini. Data kajian ini diperoleh dengan cara mengkaji dokumendokumen organisasi, tulisan-tulisan ulama dan tokohnya, dan kurikulum pendidikannya. Data yang diperoleh akan direduksi, disistematisasi dan diinterpretasi, dipaparkan dan setelah itu dilakukan penarikan kesimpulan.

\section{Historisitas Al Jam'iyatul Washliyah}

Al Jam'iyatul Washliyah merupakan organisasi sosial keagamaan yang didirikan di Medan, Sumatera Utara, Indonesia, pada tanggal 30 November 1930, oleh para pelajar dari etnis Mandailing yang belajar agama di Maktab Islamiyah Tapanuli (MIT) dan atau Madrasah Hasaniyah. ${ }^{10}$ Para pelajar tersebut antara lain Ismail Banda, Abdurrahman Syihab, Yusuf Ahmad Lubis, Adnan Nur Lubis dan M. Arsjad Thalib Lubis. Satu di antara mereka tidak pernah belajar di MIT, yaitu M. Arsjad Thalib Lubis. Kelak, mereka merupakan ulama terkenal di Sumatera Utara, dan afiliasi politik mereka adalah Partai Masyumi, kecuali Adnan Nur Lubis yang berafiliasi dengan Partai Nasionalis Indonesia (PNI). MIT, tempat mereka belajar agama, merupakan madrasah yang

\footnotetext{
10 Abdurrahman Sjihab, "Memperingati Al-Djam'ijatul Washlijah 21 Tahun 30 November 1930-30 November 1951", dalam M. Husein Abd. Karim, 21 Al Dj. Washlijah (Medan: Pustaka Al Washlijah, 1951), 2.
} 
didirikan oleh para perantau Mandailing di Medan. Dahulu, Medan merupakan pusat pemerintahan Kerajaan Deli. Bekas istana kerajaan ini masih berdiri kokoh di sekitar Masjid Raya al-Mashun yang juga merupakan warisan Kerajaan Deli. Sebagai kota yang berkembang semasa kolonial Belanda, banyak orang-orang Mandailing dari Keresidenan Tapanuli yang berbatasan dengan Sumatera Barat merantau ke Medan dengan tujuan bekerja atau belajar. Tidak sedikit dari perantau Mandailing yang memahami agama dengan baik. Di Medan, sejumlah tokoh Mandailing menyiapkan pendidikan agama untuk anak-anak mereka. Karenanya, mereka mendirikan Maktab Islamiyah Tapanuli, disingkat MIT. Madrasah ini diresmikan pada tanggal 18 Mei 1918. ${ }^{11}$ Para pendiri madrasah ini adalah Shaykh Muhammad Ya'cub, dan guru-gurunya antara lain Shaykh Muhammad Yunus dan Shaykh Dja'far Hasan. MIT merupakan madrasah yang bertujuan untuk melestarikan mazhab Shāficiyah dan Abl al-Sunnah wa al-Jamāah dan ini dimungkinkan dicapai karena banyak guru MIT belajar agama dalam konteks mazhab Sunni kepada ulamaulama di Masjid al-Harām. Dalam bidang tauhid, menurut Mahmud Yunus, ${ }^{12}$ guru-guru MIT mengajar kitab Jawhar al-Tawhid dan Sullam al-Tawfiq, dan para pelajarnya wajib menghafal isi kitab tersebut. MIT sebagai media pelestarian doktrin Sunni menjadi alasan historis mengapa Al Washliyah mengajarkan karya-karya mazhab Sunnī dan ulama-ulamanya menulis karya tulis menurut mazhab ini.

Selain belajar agama dalam tradisi Sunnī di MIT, para pendiri Al Washliyah belajar dan mendalami agama tingkat lanjut kepada Shaykh Hasan Maksum yang merupakan murid sejumlah ulama di Masjid al-Ḥarām, termasuk Shaykh Aḥmad Khatīb alMinangkabawī. Di Medan, Shaykh Hasan Maksum mendirikan Madrasah Hasaniyah dan mengajarkan kitab-kitab mazhab Shāfíīyah dan Ash`ārīyah. Mahmud Yunus ${ }^{13}$ mengakui bahwa Shaykh Hasan Maksum memiliki keahlian dalam bidang ilmu-ilmu

11 Lihat sejarah Maktab Islamiyah Tapanuli dalam studi yang dilakukan Muaz Tanjung, Maktab Islamiyab Tapanuli 1918-1942: Menelusuri Sejarab Pendidikan Islam Awal Abad ke-20 di Medan (Medan: IAIN Press, 2012).

12 Mahmud Yunus, Sejarab Pendidikan Islam di Indonesia (Jakarta: Hidakarya Agung, 1993), 193.

${ }^{13}$ Ibid., 192. 
agama (tauhid, fiqh, tafsir dan hadìth), bahasa Arab, tasawuf, ilmu hisab, dan ilmu falak. Ulama Melayu ini juga menulis karya-karya dalam bidang fiqh Shāfí̄yah dan tauhid Ash'ārīyah dalam bahasa Melayu dengan aksara Arab atau yang biasa disebut Arab-Melayu. Tentu saja, murid-muridnya yang kelak mendirikan Al Washliyah juga melestarikan mazhab Sunn̄̄ melalui organisasi Islam yang mereka dirikan. Terbukti, madrasah-madrasah Al Washliyah mengajarkan kitab kuning warisan ulama Sunnī.

Al Washliyah pada periode awal sangat didominasi oleh orangorang Mandailing, dan beberapa tahun kemudian barulah orangorang Melayu masuk sebagai pengurus. Al Washliyah menjadi wadah bagi kelompok terpelajar dari etnis Mandailing Muslim. Sampai saat ini, organisasi ini mendapatkan dukungan dari beragam kelompok yang berlatar suku yang beragam pula mulai dari Melayu, Aceh, Banjar, Batak, Karo, dan Jawa. Akan tetapi, masih banyak pemimpin Al Washliyah di Sumatera Utara atau di level Pengurus Besar Al Washliyah yang berasal dari etnis Mandailing. Karenanya, iklim Mandailing masih begitu melekat dalam organisasi ini. Mungkin pengamat akan menanti-nanti orang-orang non-Mandailing akan memimpin organisasi asal Kota Medan, Sumatera Utara ini. Dari perspektif ideologi, orang-orang Mandailing menganut mazhab Sunnī, dan ulama-ulama yang berasal dari etnis ini menjadi penerus tradisi Sunnī di Nusantara bahkan Haramayn. Ada dua ulama Mandailing yang terkenal di Haramayn, yaitu Shaykh 'Abd al-Qādir b. Șābir al-Mandilī (Nasution) dan Shaykh 'Abd al-Qādir b. 'Abd al-Muțtalib alMandilī, di mana kedua ulama ini mengajar di Masjid al-Ḥarām sampai akhir hidup mereka. Banyak ulama Mandailing belajar agama di Mekah dan menjadi penerus tradisi Sunnī di kampung halaman masing-masing misalnya Shaykh Musthafa Husein (Nasution). Ulama-ulama Al Washliyah juga belajar agama di Haramayn, baik secara intens maupun sebentar, dengan ulamaulama Sunnī di Ḥaramayn. Dengan demikian, orang-orang Islam dari etnis Mandailing berafiliasi dengan mazhab Sunnī.

Al Washliyah mendedikasikan potensinya kepada umat dalam bidang pendidikan, dakwah, dan amal sosial. Pada era belakangan, bidang ekonomi menjadi amal usahanya yang keempat. Al Washliyah memang telah berdiri di luar Sumatera Utara, hanya cukup terlambat dalam meluaskan pengaruhnya di Jawa, 
Kalimantan, Sulawesi, dan Papua. Dalam aspek pendidikan, pada tahun 1955, menurut Udin Sjamsuddin, ${ }^{14}$ Al Washliyah mengelola 250 sekolah agama dan sekolah umum. Dalam aspek dakwah, Al Washliyahmenyiarkan Islam untuk umat Islam dan orang-orang yang belum beragama di Sumatera Utara, khususnya Tapanuli Utara, Nias, dan Karo. ${ }^{15}$ Sampai tahun 1970 -an, Al Washliyah giat dalam mengembangkan dakwah kepada internal umat Islam dan juga aktif mengislamisasikan orang-orang yang belum beragama Islam termasuk berdebat dengan beberapa pendeta Kristen. ${ }^{16}$ Dalam bidang amal sosial, Al Washliyah sejak awal memberikan perhatian terhadap masa depan anak yatim, piatu, fakir dan miskin dengan mendirikan panti asuhan yang berada di bawah pengawasan Madjlis Anak Miskin dan Jatim Pijatu. ${ }^{17}$ Meskipun mengklaim bahwa ada empat amal usaha yang menjadi fokus $\mathrm{Al}$ Wașliyah, akan tetapi tampaknya Al Washliyah lebih fokus pada pengelolaan lembaga pendidikan mulai dari tingkat madrasah diniyah sampai perguruan tinggi, meskipun masih terpusat di Sumatera Utara bagian timur, dan saat ini sudah memiliki sedikit lembaga pendidikan di Aceh, DKI Jakarta, Banten, Jawa Barat, Jawa Tengah, dan Kalimantan Selatan. Namun tidak bisa dipungkiri, lembaga-lembaga pendidikan Al Washliyah relatif berhasil menjadi media pelestarian mazhab Sunnī di Nusantara.

${ }^{14}$ Udin Sjamsuddin, “Tjatetan Ringkas Dari Sedjarah Perkembangan Organisasi Al Djam. Washlijah”, dalam M. Husein Abd. Karim, 21 Al Dj. Washlijah (Medan: Pustaka Al Washlijah, 1951), 21.

${ }^{15}$ M. Arsjad Th. Lubis, "Penjiaran Islam Al Dj. Washlijah", dalam M. Husein Abd. Karim, 21 AlDj. Washlijah (Medan: Pustaka Al Washlijah, 1951), 36-39.

16 Untuk melawan gerakan Kristenisasi, misalnya, Al Washliyah menerbitkan artikel-artikel tentang agama Kristen dalam majalah Medan Islam yang awalnya dipimpin oleh M. Arsjad Thalib Lubis. Majalah Medan Islam merupakan majalah yang diterbitkan Pengurus Besar Al Jam'iyatul Washliyah. Majalah ini dipimpin oleh M. Arsjad Thalib Lubis dan Abdul Wahab. Di antara para pembantu majalah ini adalah Ibnoe Banda (Ismail Banda) di Mekah, Abdul Wahab di Kairo dan A. Kadir di Porsea, Tapanuli Utara. Banyak artikel tentang agama Kristen yang diterbitkan majalah ini dalam bentuk kritik ajaran, di antaranya ditulis oleh Yusuf Ahmad Lubis yang merupakan salah seorang pendiri Al Washliyah dan pakar Kristologi di mana ia menulis banyak buku tentang perbandingan Islam dan Kristen. Lihat misalnya sebuah artikel berjudul "Orang Kristen tidak Benar Pertjaja kepada Nabi Isa”, Medan Islam, Nomor 9, Tahoen ke-II, 8-10.

17 Mhd. Nurdin, "Riwajat Ringkas dan Pendjelasan Madjlis Anak Miskin dan Jatim Pijatu 'Al Djamijatul Washlijah”, dalam M. Husein Abd. Karim, 21 Al Dj. Washlijah (Medan: Pustaka Al Washlijah, 1951), 51. 
Harus diakui, usaha Al Washliyah dalam bidang dakwah dan amal sosial tidak segiat usahanya dalam bidang pendidikan. Usaha dakwah di kawasan minoritas Islam di Sumatera Utara tidak segencar masa-masa awal Al Washliyah yang giat melakukan islamisasi di Tapanuli Utara, Karo dan Nias. Usaha Al Washliyah dalam bidang pemberdayaan ekonomi umat juga belum begitu menonjol. Selain bidang pendidikan, sebenarnya usaha dalam bidang dakwah, amal sosial dan pemberdayaan ekonomi umat mampu memperkuat gerakan organisasi Islam ini dalam mempertahankan tradisi Islam Sunnī di Nusantara, dan ke depan idealnya tiga amal usaha ini harus mendapatkan perhatian intens dari pengurus Al Washliyah.

Dari aspek politik, harus ditegaskan bahwa Al Washliyah tidak pernah menjadi partai politik atau menginisiasi pendirian partai politik. Hanya saja, di era Orde Lama, Al Washliyah pernah menjadi anggota istimewa partai Masyumi sampai tahun $1959 .{ }^{18}$ Di era Orde Baru, tokoh-tokoh Al Washliyah menjadi deklarator Parmusi di Sumatera Utara. Bahkan Al Washliyah diidentikkan dengan Partai Persatuan Pembangunan (PPP), meskipun beberapa kadernya berafiliasi dengan Golkar di era Orde Baru. Di era Reformasi, kader-kader Al Washliyah berafiliasi ke berbagai partai seperti Partai Golongan Karya (Golkar), Partai Umat Islam (PUI), Partai Bulan Bintang (PBB), Partai Demokrat, PPP, Partai Keadilan Sejahtera (PKS), Partai Demokrasi Indonesia Perjuangan (PDI-P) dan Partai Hati Nurani Rakyat (Hanura). Dalam beberapa momen Pemilihan Kepala Daerah di Sumatera Utara pascaReformasi, Al Washliyah terlibat dukung mendukung calon kepala daerah, akan tetapi organisasi Islam ini hanya mendukung dan memperjuangkan kemenangan bagi pasangan yang berasal dari kaum Muslim, dan menolak untuk mendukung calon kepala daerah dari "pasangan pelangi" atau pasangan Muslim dan non-Muslim,

18 Pengurus Besar Al Djam'ijatul Washlijah, Putusan-putusan Kongres Al Dj. Washlijah ke-XI Tanggal 27 s/d 30 Nopember 1959 di Medan (Medan: Pengurus Besar Al Djamijatul Washlijah, 1959), 85-86. 
apalagi pasangan non-Muslim. ${ }^{19}$ Jika didalami lebih lanjut tentang argumen keputusan politik $\mathrm{Al}$ Washliyah, maka akan terlihat bahwa doktrin Sunn̄i tentang kewajiban memilih pemimpin Muslim, bukan pemimpin non-Muslim, sangat mempengaruhi ideologi politik organisasi dan konstituen ormas Islam ini. Mungkin akan muncul klaim bahwa Al Washliyah bukan organisasi yang toleran karena menolak kepemimpinan non-Muslim, meskipun keputusan politik tersebut lebih sebagai dampak dari akidah yang dianut oleh organisasi ini yaitu Abl al-Sunnah wa al-Jamäab dan fikih yang dipanuti dan diamalkan yaitu Shāfi'îyah. Dengan demikian, keputusan politik Al Washliyah kerap didasari dan dipengaruhi oleh pandangan-pandangan ulama Sunnī klasik.

\section{Religiusitas Al Jam'iyatul Washliyah}

Abdurrahman Syihab ${ }^{20}$ sebagai salah seorang pendiri organisasi ini menyebutkan bahwa maksud dan tujuan $\mathrm{Al}$ Washliyah adalah "melaksanakan tuntutan agama Islam." Menurut Syihab, maksud dan tujuan $\mathrm{Al}$ Washliyah mengalami perkembangan di mana pada tahun 1947, maksud dan tujuan organisasi ini adalah "melaksanakan tuntutan agama Islam dan kesempurnaan kedaulatan Republik Indonesia yang berdasarkan Ketuhanan Yang Maha Esa”. Udin Sjamsuddin ${ }^{21}$ yang pernah menjadi Ketua Umum Pengurus Besar (PB) Al Washliyah menjelaskan dalam salah satu pidatonya pada tahun 1955 bahwa tujuan Al Washliyah ketika diresmikan pertama sekali adalah "memajukan, mementingkan dan menambah tersiarnya agama Islam". Empat tahun kemudian, tujuan ini direvisi menjadi "berusaha menunaikan tuntutan agama Islam." Berdasarkan informasi dari dua tokoh awal Al Washliyah tersebut, menarik dilihat bahwa redaksi maksud dan tujuan $\mathrm{Al}$ Washliyah merespons perkembangan politik di Indonesia. Sebelum kemerdekaan, disebutkan bahwa Al Washliyah bermaksud dan

19 Lihat ulasan ini dalam Ja'far, “Al Jam'iyatul Washliyah dan Problem Kepemimpinan NonMuslim dan Perempuan", dalam Abkam: Jurnal Ilmu Syariah, Vol. 17, No. 2 (2017), 413-434. Diskursus tentang kepemimpinan non-Muslim, lihat studi Mary Silvita, "Presiden Non-Muslim dalam Komunitas Masyarakat Muslim”, IslaImica: Jurnal Studi Keislaman, No. 7, No. 1 (2012), 44-60.

${ }^{20}$ Sjihab, “Memperingati Al Djam’ijatul Washlijah 21 Tahun”, 2.

21 Udin Sjamsuddin, Chutbah Pengurus Besar Memperingati Ulang Tabun Al Djamijatul Washlijah Seperempat Abad: 30 November 1930-30 November 1955 (Medan: Pengurus Besar Al Djamijatul Washlijah, 1955), 2. 
bertujuan untuk menjadi organisasi yang ingin melaksanakan tuntutan agama Islam, akan tetapi setelah Indonesia merdeka berubah sebagaimana disebut oleh Abdurrahman Syihab di atas.

Sejak awal berdiri, Al Washliyah merupakan organisasi yang berasaskan Islam, akan tetapi menganut mazhab Shāfici dalam bidang fiqh, dan Abl al-Sunnah wa al-Jamāáah dalam bidang akidah. Dalam Anggaran Dasar tahun 1962, disebutkan bahwa "perkumpulan ini berazas Islam, dalam hukum fikih bermazhab Syafici dan dalam i'tiqad Ahlussunnah wal djamaah". ${ }^{22}$ Dalam perspektif akidah, Al Washliyah menganut mazhab Abl al-Sunnah wa al-Jamäah. Para pendiri Al Washliyah mengutip pendapat Shaykh Muhammad al-Amīr dalam kitabnya yang berjudul Hāshiyah Ibn al-Amìr 'alā Itḥäf al-Murìd Sharḅ Jawhar al-Tawhìd terkait maksud mazhab Abl al-Sunnah wa al-Jamāah, yaitu "orang yang mengikuti sunnah (jalan) Nabi Muhammad, yaitu jalan yang telah ditempuh orang-orang saleh dahulu kala yang beralaskan kepada al-Qur'ān dan Hadīth." Kitab Hāshiyah Ibn al-Amìr ditulis oleh Muḥammad b. Muḥammad b. Aḥmad b. 'Abd al-Qādir al-Sanbāwī al-Azharī (w. 1816), yang merupakan ulama alumnus Universitas al-Azhar yang menulis 13 karya häshiyah. Al Washliyah dalam hal ini meyakini hadīth nabi yang menyatakan bahwa umat Islam akan terbagi menjadi 73 golongan, 72 golongan akan masuk neraka dan hanya satu golongan yang akan masuk surga, yaitu jamá'ah, yang merupakan golongan orang yang mengikuti jalan Nabi yang diteruskan oleh sahabat-sahabat Nabi setelah Nabi wafat. Al Washliyah mengutip pendapat 'Abd al-Qādir al-Tamimī bahwa jamāah adalah golongan yang lepas dari api neraka. ${ }^{23}$ Ramli Abdul Wahid sebagai Ketua Dewan Fatwa Al Washliyah (2015-2020) menambahkan bahwa mazhab Abl al-Sunnah wa al-Jamā'ab didirikan oleh Abū al-Hasan al-Ash'ārī yang merupakan pendiri mazhab Ash‘ārīyah. Sebab itulah, karya para ulama mazhab Ash‘ārīyah menjadi rujukan bagi $\mathrm{Al}$ Washliyah, khususnya ulama dan madrasah yang dikelola organisasi ini. Madrasah-madrasah $\mathrm{Al}$

\footnotetext{
22 Pengurus Besar Al Djamijatul Washlijah, "Anggaran Dasar dan Anggaran Rumah Tangga”, dalam Putusan-putusan Muktamar Al Dj. Washlijah ke-XII Tanggal 30 Nop. s/d 4 Desember 1962 di Langsa (Medan: Pengurus Besar Al Djamijatul Washlijah, 1962), 101.

${ }^{23}$ Sjamsuddin, Chutbah Pengurus Besar, 5.
} 
Washliyah, menurut Ramli, ${ }^{24}$ mengajarkan kitab-kitab mazhab Ash'ārīyah terutama kitab yang mengkaji masalah sifat dua puluh, dan beberapa ulama organisasi ini telah menghasilkan kitab-kitab yang membahas masalah serupa.

Adapun latar belakang Al Washliyah menganut mazhab Abl alSunnab wa al-Jamäab adalah karena tiga faktor. Pertama, para pendiri Al Washliyah dan guru-guru mereka merupakan penganut mazhab ini. Di antara mereka adalah Ismail Banda, M. Arsjad Thalib Lubis, Yusuf Ahmad Lubis, dan Abdurrahman Syihab. Guru-guru mereka adalah Shaykh Hasan Maksum, Shaykh Muhammad Yunus dan Shaykh Dja'far Hasan. ${ }^{25}$ Kedua, mayoritas penduduk Muslim di Sumatera Timur menganut mazhab ini. Sumatera Timur merupakan salah satu keresidenan di era kolonial di mana terdapat beberapa kerajaan Melayu di kawasan ini, di antaranya Kerajaan Deli. Mazhab resmi kerajaan-kerajaan di Sumatera Timur adalah mazhab Abl al-Sunnah wa al-Jamäah, sehingga penduduk di setiap kerajaan juga menganut mazhab tersebut. Lembaga-lembaga pendidikan Islam yang diakui kerajaan juga mengajarkan dan menjadi agen penyebaran mazhab Abl al-Sunnab wa al-Jamäah dalam bidang akidah dan mazhab Shāfíi dalam bidang hukum Islam (figh). Ketiga, alumni lembaga pendidikan Islam di Sumatera Timur banyak yang melanjutkan pendidikan agama mereka ke pusat intelektual mazhab Sunni terutama di Mekah, Madinah, dan Kairo. Di antara mereka adalah Ismail Banda, Adnan Lubis, dan M. Husein Abd. Karim. Di Timur Tengah, mereka belajar ilmuilmu ke-Islaman menurut mazhab Sunnī dan memperoleh sanad keilmuan dalam mazhab ini, dan akhirnya mereka menjadi para penerus dan pengawal mazhab tersebut di Sumatera Timur sepulang dari Timur Tengah.

Untuk mengawal organisasi dalam bidang keagamaan, Al Washliyah mendirikan Dewan Fatwa Al Washliyah pada tahun 1933 yang awalnya bernama Majelis al-Fatwa. Tujuan pendirian lembaga ini adalah untuk menjawab persoalan-persoalan yang

\footnotetext{
24 Ramli Abdul Wahid, "Akidah Al Washliyah", dalam http://kabarwashliyah.com, 21 Januari 2014.

25 Lihat biografi mereka dalam Ja'far, Tradisi Intelektual Al Washliyab: Biografi Ulama Kharismatike dan Tradisi Keulamaan (Medan: Perdana Publishing, 2015), atau dalam Ja'far, Biografi Ketua Umum Pengurus Besar Al Jam'iyatul Washliyah 1930-2015 (Medan: Perdana Publishing, 2015).
} 
dihadapi organisasi dan masyarakat terkait masalah-masalah keagamaan. Di antara tokoh teras lembaga ini antara lain adalah Shaykh Hasan Maksum, Shaykh Abdul Wahab Lubis, Yusuf Ahmad Lubis, H. Bahrum Djamil, M. Ridwan Ibrahim Lubis, Jalaluddin Abdul Muthalib, KH. Totoh Abdul Fatah dan Ramli Abdul Wahid. ${ }^{26}$ Dewan Fatwa Al Washliyah hanya ada di tingkat Pengurus Besar saja. Tidak banyak sidang fatwa yang diadakan lembaga ini, sehingga tidak banyak fatwa yang dihasilkan. Fatwafatwa yang dihasilkan belum diterbitkan, meskipun usaha ke arah itu sudah mulai dilakukan. Fatwa-fatwa yang telah dikeluarkan dicetak secara terbatas, dan fatwa-fatwa terbaru disosialisasikan melalui internet, khususnya website resmi $\mathrm{Al}$ Washliyah ataupun media sosial Facebook dan Whats App. Penggunaan internet kurang dimaksimalkan oleh organisasi ini untuk menyebarkan ideologi, gagasan, dan kiprah organisasi, meski dunia saat ini sudah memasuki era revolusi industri 4.0 yang lahir sebagai dampak nyata dari perkembangan teknologi informasi.

Madjlis al-Fatwa mengadakan sidang fatwa perdana pada bulan Oktober 1938 di Medan, ${ }^{27}$ lima tahun setelah berdiri. Artinya, selama lima tahun berdiri, lembaga fatwa ini ternyata tidak mengadakan kegiatan untuk hanya sekadar mengeluarkan satu atau dua fatwa sekalipun. Mungkin, persoalan organisasi dan agama masih bisa ditanya langsung oleh ulama secara individu, apalagi Shaykh Hasan Maksum sebagai mufti Kerajaan Deli masih hidup dan fatwanya sangat dihormati dan dipatuhi. Setelah ia wafat pada tahun 1936, mungkin tidak ada ulama yang selevel dengan Shaykh Hasan Maksum, sehingga para tokoh Al Washliyah mulai memberdayakan lembaga ini untuk meneruskan peran Shaykh Hasan Maksum sebagai pemberi fatwa keagamaan, sehingga dalam konteks ini ada perubahan dalam cara mengeluarkan fatwa, dari fatwa agama yang dikeluarkan secara individual oleh seorang ulama menjadi mengeluarkan fatwa secara kolektif. Peran Shaykh Hasan Maksum digantikan oleh Madjlis al-Fatwa ini. Pada tahun 1938, Madjlis al-Fatwa mengeluarkan lima fatwa tentang mentonilkan nabi-nabi, riba, fitrah anak yatim, lotre, dan mandi safar. Fatwa

\footnotetext{
${ }^{26}$ Ja'far, "Respons Dewan Fatwa Al Jam'iyatul Washliyah terhadap Isu Akidah dan Syariah di Era Global", dalam al-Manahij: Jurnal Kajian Hukum Islam, Vol. 10, No. 1 (2016), 102.

${ }^{27}$ Sjamsuddin, Chutbah Pengurus Besar, 13.
} 
Madjlis al-Fatwa yang jarang diungkap adalah fatwa jihad sebagai respons $\mathrm{Al}$ Washliyah terhadap kemerdekaan Indonesia dan perjuangan bangsa Indonesia dalam mempertahankan kemerdekaan Indonesia dari kolonial Belanda. Fatwa jihad tersebut, yang diumumkan pada tahun 1945 di Pematang Siantar, adalah: "Wadjib atas tiap2 ummat Islam di Indonesia menolak kedatangan orang2 Belanda dan pembantu-pembantunja jang hendak berkuasa di Indonesia. Orang Islam jang mati dalam pertempuran tersebut dengan niat menegakkan agama Islam, dihukumkan sjahid fi sabilillah" 28

Sangat disayangkan fatwa-fatwa Madjlis al-Fatwa atau Dewan Fatwa Al Washliyah tidak dikodifikasi secara baik, meskipun diketahui dan disadari bahwa tidak banyak fatwa yang dikeluarkan oleh lembaga ini di periode-periode awal. Di era terkini, mayoritas fatwa yang dihasilkan Dewan Fatwa Al Washliyah lebih merupakan masalah-masalah hukum seperti ibadah (salat, puasa, zakat, dan haji), muamalah, dan politik, dan hanya beberapa fatwa yang berbicara masalah keyakinan misalnya komunisme, Shī'ah dan Ahmadiyah. Sikap Al Washliyah terhadap komunisme dan Ahmadiyah sangat tegas, di mana organisasi ini mengharamkan komunisme dan menilai bahwa Ahmadiyah adalah aliran sesat. Dewan Fatwa Al Washliyah periode 2010-2015 pernah mengeluarkan fatwa tentang Shī'ah yang dinilai bukan aliran sesat, tetapi pengurus belakangan mempersoalkannya karena fatwa itu dinilai tidak diputuskan lewat sidang fatwa. Fatwa tentang Shī‘ah diambil oleh pimpinan Dewan Fatwa Al Washliyah saja. Beberapa peneliti telah mengadakan riset tentang Dewan Fatwa $\mathrm{Al}$ Washliyah, tetapi semuanya membahas fatwa-fatwa lembaga ini dalam bidang hukum Islam saja, dan sebabnya adalah sedikitnya fatwa yang dikeluarkan lembaga ini terkait persoalan akidah. Hanya saja, Ramli Abdul Wahid sebagai Ketua Dewan Fatwa Al Washliyah periode 2015-2020 dan Ketua Komisi Fatwa MUI Sumatera Utara memiliki perhatian serius terhadap perkembangan aliran sesat di Indonesia dan bahkan ia sempat dijuluki oleh beberapa koleganya sebagai pakar aliran sesat. Beberapa bukunya memuat pembahasan tentang aliran sesat di Indonesia. Ia bahkan menulis buku yang secara khusus mengkritisi akidah Ahmadiyah, dan dalam beberapa kesempatan mengkritisi aliran Shī'ah dan

${ }^{28}$ Ibid., 13. 
perkembangannya di Indonesia. ${ }^{29}$ Dahulu, Abdurrahman Syihab dan M. Arsjad Thalib Lubis membentuk lembaga yang hendak memberantas aliran Ahmadiyah yang masuk ke Sumatera Timur. Memang tidak bisa dipungkiri bahwa Dewan Fatwa Al Washliyah sebagai sebuah lembaga shari`ah Al Washliyah kurang memberikan perhatian tentang persoalan akidah di era kontemporer, meskipun pengurus-pengurus lembaga ini sebagai individu memainkan peran sebagai benteng bagi tradisi Abl al-Sunnah wa al-Jamāarah di Indonesia lewat posisi mereka sebagai dai, penulis, dan pendidik (guru dan dosen).

Al Washliyah mendirikan organisasi bagian yang ditujukan kepada beragam tingkatan dalam masyarakat untuk mencapai citacita organisasi. Untuk kaum wanita dewasa, Al Washliyah mendirikan Puteri Al Washliyah yang kemudian menjadi Muslimat Al Washliyah. Kemudian, Al Washliyah mendirikan organisasi untuk kalangan pemuda dan pemudi, yaitu Gerakan Pemuda Al Washliyah (GPA), ${ }^{30}$ dan Angkatan Puteri Al Washliyah (APA). Untuk kalangan pelajar dan mahasiswa, Al Washliyah mendirikan Ikatan Pelajar Al Washliyah (IPA), ${ }^{31}$ dan Himpunan Mahasiswa Al Washliyah (HIMMAH). Untuk kalangan intelektual, Al Washliyah mendirikan Ikatan Sarjana Al Washliyah (ISARAH), dan Ikatan Guru dan Dosen Al Washliyah (IGDA). Tujuh organisasi bagian Al Washliyah ini secara ideologis tunduk dan patuh terhadap asas dan akidah $\mathrm{Al}$ Washliyah. ${ }^{32}$ Karena itu, ketujuhnya berasaskan Islam dan menganut mazhab Abl al-Sunnah wa al-Jamá'ah dalam bidang akidah dan mazhab Shāfíīyah dalam bidang hukum Islam. Akidah dan fiqh Al Washliyah juga dicantumkan dalam Anggaran

\footnotetext{
${ }^{29}$ Ja'far dan Irwansyah (eds.), Anak Desa Tak Bertuan Jadi Profesor: Kisah Nyata Kebidupan 60 Tabun Prof. Dr. Drs. Ramli Abdul Wabid, Lc., MA (Medan: Manhaji, 2016).

30 Mengenai organisasi pemuda Al Washliyah ini, lihat Ja'far, Dari Tanah Deli Untuk Negeri: Historisitas, Religiusitas dan Nasionalisme Gerakan Pemuda Al Washliyah (Yogyakarta: K-Media, 2019).

31 Mengenai organisasi pelajar Al Washliyah ini, lihat Ja'far, Ikatan Pelajar Al Washliyah: Gerakan, Identitas dan Ideologi Pelajar Muslim di Nusantara 1953-2017 (Medan: Perdana Publishing, 2018).

32 Pimpinan Pusat Gerakan Pemuda Al Washlijah, "Anggaran Dasar Gerakan Pemuda Al Washlijah”, dalam Nukman Sulaiman (ed.), Peringatan Al Djamijatul Washlijah 1/4 Abad (Medan: Pengurus Besar Al Djamijatul Washlijah, 1956), 358; Pimpinan Pusat Puteri Al Washlijah, "Anggaran Dasar Putri Al Washlijah", dalam Sulaiman (ed.), Peringatan Al Djamijatul Washlijah, 353.
} 
Dasar ketujuh organisasi bagiannya tersebut. Dengan demikian, ketujuh organisasi bagian Al Washliyah tersebut juga memiliki tanggung jawab yang sama dengan induknya sebagai organisasi Islam yang mempertahankan dan melestarikan tradisi Sunnī di Nusantara. Itulah sebabnya, kegiatan-kegiatan yang diselenggarakan oleh $\mathrm{Al}$ Washliyah dan tujuh organisasi bagiannya didasari dan tidak bertentangan dengan ajaran Islam, khususnya maz̧hab Abl al-Sunnah wa al-Jamā'ah dan Shāfíìyah.

\section{Peran Ulama Al Washliyah dalam Pelestarian Akidah}

Iktikad Abl al-Sunnah wa al-Jamäah merupakan keyakinan organisasi Al Washliyah. Penisbahan iktikad aliran ini tidak lain didasarkan pada keyakinan para pendirinya dan guru-guru mereka. Para pendiri Al Washliyah adalah sejumlah alumnus MIT dan Madrasah Hasaniyah. Di antara pendiri Al Washliyah adalah Ismail Banda, Abdurrahman Syihab, M. Arsjad Thalib Lubis, Yusuf Ahmad Lubis dan Adnan Nur Lubis. Guru mereka di MIT adalah Shaykh Muhammad Yunus, sedangkan di Madrasah Hasaniyah mereka belajar kepada Shaykh Hasan Maksum. Shaykh Muhammad Yunus merupakan ulama yang memberi nama $\mathrm{Al}$ Jam'iyatul Washliyah ini belajar di banyak tempat, terutama di Mekah dan di sana ia berguru kepada sejumlah ulama, di antaranya Shaykh 'Abd al-Qādir al-Mandilī (Nasution) yang merupakan penulis kitab tauhid yang berjudul Fath al-Rahmān. Shaykh Hasan Maksum juga berguru kepadanya, selain kepada Shaykh Ahmad Khațīb al-Minangkabawī yang juga guru Shaykh Ahmad Dahlan (Muhammadiyah) dan Shaykh Hasyim Asy'ari (NU). ${ }^{33}$ Dari Shaykh 'Abd al-Qādir al-Mandilī dan Shaykh Aḥmad Khaṭīb alMinangkabawī, sanad keilmuan mereka menyambung sampai kepada al-Shāfíī, Abū al-Ḥasan al-Ash'ārī, dan Abū al-Manșūr alMāturīdī ${ }^{34}$ di mana ketiganya merupakan tokoh sentral dalam tradisi Sunnī.

\footnotetext{
${ }^{33}$ Ahmad Fauzi Ilyas, "Shaykh Ahmad Khatib Minangkabau dan Polemik Tarekat Naqsyabandiyah di Nusantara", dalam Journal of Contemporary Islam and Muslim Societies, Vol. 1, No. 1 (2017).

34 Ja'far, "Tarekat dan Gerakan Sosial Shaykh Hasan Maksum", dalam TEOSOFI: Jurnal Tasawnf dan Pemikiran Islam, Vol. 5, No. 2 (2015); Ja'far, "Peran Al Jam'iyatul Washliyah dalam Merevitalisasi Mazhab Shafi'i di Era Kontemporer", dalam Justicia Islamica: Jurnal Kajian Hukum dan Sosial, Vol. 13, No. 1 (2016); Arwin Juli Rakhmadi Butar-butar, "Kajian Ilmu Falak di
} 
Ulama-ulama Al Washliyah turut mengembangkan dan memperkuat mazhab Abl al-Sunnah wa al-Jamäab dengan menulis buku-buku tauhid yang sebagiannya dijadikan buku teks madrasahmadrasah Al Washliyah. Beberapa di antara mereka seperti M. Arsjad Thalib Lubis, M. Husein Abd Karim, Nukman Sulaiman, Abd. Majid Siradj, Hamdan Abbas, dan Lahmuddin Nasution menulis buku dalam bidang tauhid. Sedangkan Ramli Abdul Wahid menulis buku bercorak tauhid dengan fokus pembahasan kritik terhadap aliran Ahmadiyah. Rasyad Yahya juga menulis buku berjudul Ilmu Taubid yang ditujukan untuk kalangan pelajar Madrasah Ibtidaiyah. Mereka, selain pernah menjadi guru di madrasah-madrasah Al Washliyah dan dosen di UNIVA Medan, juga menjadi pengurus teras organisasi Al Washliyah.

Paling tidak ada tujuh ulama Al Washliyah di Sumatera Utara yang berperan aktif dalam menyebarkan mazhab Abl al-Sunnab wa al-Jamäah melalui media tulisan, sedangkan kebanyakan lainnya menyebarkan mazhab tersebut dengan mengajarkan kitab-kitab tauhid di lembaga pendidikan yang dikelola Al Washliyah. Ulama pertama adalah M. Arsjad Thalib Lubis yang merupakan salah seorang ulama pendiri organisasi Al Washliyah. Ia adalah murid Shaykh Hasan Maksum, mufti Kerajaan Deli di Medan, sedangkan Shaykh Hasan Maksum merupakan murid dari Shaykh 'Abd alQādir al-Mandilī dan Shaykh Aḥmad Khațîb al-Minangkabawī di Masjid al-Ḥarām. Arsjad banyak menghasilkan buku. Dalam bidang tauhid, ia menulis buku pelajaran untuk tingkat Tajhiziyah yang berjudul Pelajaran Iman. Kitab ini ditulis dalam bahasa Arab Melayu dan berisikan masalah rukun iman, tidak tebal tetapi mudah dipahami oleh anak-anak. Kitab ini terus mengalami cetak ulang dari tahun 1940-an sampai sekarang, dan belakangan diterbitkan oleh Penerbit Sumber Ilmu Jaya. Beberapa karyanya yang lain terbit dan beredar di Malaysia.

Selain itu, Arsjad juga menulis buku tipis yang berjudul al-

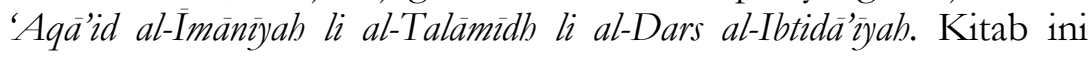
diterbitkan oleh Sumber Ilmu Jaya di Medan dalam bahasa Arab dan setebal 16 halaman. Kedua kitab ini terus dijadikan sumber referensi sampai saat ini dan digunakan oleh guru-guru Madrasah Diniyah Takmiliyah Awwaliyah (MDTA) di Sumatera Utara,

Indonesia: Kontribusi Syaikh Hasan Maksum dalam Bidang Ilmu Falak", dalam Journal of Contemporary Islam and Muslim Societies, Vol. 1, No. 1 (2017). 
khususnya MDTA yang dikelola oleh Al Washliyah di Medan, Deli Serdang, Serdang Bedagai, Batu Bara, Asahan dan Tanjung Balai. Ustaz Arsjad juga menulis buku pengantar keimanan dalam bahasa daerah di Sumatera Utara seperti Batak, Karo, dan Dairi, di mana buku ini ditujukan kepada para mualaf, yaitu orang yang baru masuk Islam. Buku tersebut di antaranya berjudul Bena-bena Kepertjajaen Ibagessen Agama Islam sebanyak 26 halaman dan Dasaring Kapertjajan Ing Agama Islam sebanyak 28 halaman. Keduanya diterbitkan oleh Sekretariat Dakwah MUI Daerah Tk. I Propinsi Sumatera Utara. Buku ini sangat bermanfaat bagi misi dakwah $\mathrm{Al}$ Washliyah di kawasan minoritas Muslim. Arsjad juga dikenal sebagai ahli perbandingan Islam dan Kristen, dan telah menulis beberapa karya yang berkenaan dengan agama Kristen.

Ulama kedua adalah M. Husein Abd. Karim yang merupakan salah seorang ulama Al Washliyah dan alumnus Madrasah Sholatiyah, Mekah. Ia pernah menjadi Ketua Al Washliyah cabang Mekah menggantikan Ismail Banda sebagai ketuanya yang pertama. Abd. Karim menulis sejumlah karya dalam bidang keislaman, di antaranya adalah Kifäyat al-Mubtadi' fì 'Im al-Kaläm yang berisikan masalah rukun iman. Kitab ini masih terus digunakan di MDTA Al Washliyah dan digunakan untuk kelas atas. Kitab ini diterbitkan oleh Penerbit Sumber Ilmu Jaya Medan, dan diterbitkan berulang kali.

Ulama ketiga adalah Nukman Sulaiman yang merupakan murid M. Arsjad Thalib Lubis dan Adnan Lubis. Selain hafiz al-Qur'ān dan sempat menjadi Rektor UNIVA Medan, ia menulis buku 'Aqidah Islamiyah: Pokok-pokok Kepercayaan dalam Islam. Buku ini diterbitkan oleh Pustaka UNIVA dan terdiri atas dua jilid. Buku ini mengulas ilmu tauhid menurut pendekatan sains, akal dan wahyu. Jilid pertama terdiri atas 100 halaman, dan mengulas pengertian akidah, Zat Allah, Sifat Allah, dan kewajiban manusia kepada Allah. Sedangkan jilid kedua berjumlah 157 halaman.

Ulama keempat adalah Abd. Majid Siradj yang merupakan satu di antara ulama Al Washliyah. Ia merupakan alumnus Universitas al-Azhar, Kairo, dan sebelumnya menamatkan studi agama di Madrasah al-Qismul 'Aly Al Washliyah di Medan. Ia termasuk murid para ulama terkemuka Sumatera Utara, seperti M. Arsjad Thalib Lubis (pakar tauhid, fiqh dan perbandingan agama), Zainal Arifin Abbas (pakar tafsir), dan Adnan Lubis (pakar tafsir). Ia 
banyak menulis karya, khususnya dalam bidang tauhid. Satu di antara karyanya adalah Ikhtisār Tlm al-Tawhìd sebanyak dua jilid dan diterbitkan oleh MPP \& K PB Al Jam'iyatul Washliyah di Medan. Dari segi halaman, buku jilid 1 berjumlah 27 halaman, sedangkan buku jilid 2 berjumlah 30 halaman. Karya ini dicetak dalam kertas ukuran legal pada tahun 1978.

Ulama kelima adalah Hamdan Abbas yang merupakan ulama Al Washliyah dan pernah menjadi Ketua MUI Propinsi Sumatera Utara. Ia menyelesaikan pendidikan keagamaannya di Madrasah Sholatiyah, Mekah. Ia menulis banyak diktat dalam bidang fiqh dan tauhid. Dalam bidang tauhid, ia menulis Perkembangan Aqidah dalam Islam. Buku ini dicetak secara terbatas tanpa penerbit dan ditulis dalam bahasa Indonesia sebanyak 101 halaman. Buku ini berisi pembahasan tentang arti tauhid, sejarah perkembangan ilmu tauhid, Qadarīyah dan Jabarīyah, tawassul, dan bid'ah.

Ulama keenam adalah Lahmuddin Nasution yang merupakan salah seorang ulama Al Washliyah, dan pernah menjadi pengurus teras Dewan Fatwa Al Washliyah. Ia merupakan Profesor dalam bidang Hukum Islam di IAIN (sekarang UIN) Sumatera Utara, dan dikenal sebagai pakar kitab kuning di Sumatera Utara. Meskipun pakar fiqh, ia pernah menerjemahkan kitab Sharḅ Umm al-Barähin karya al-Sanusī. Terjemahan dalam bahasa Indonesia ini diterbitkan oleh Penerbit Raja Grafindo Persada di Jakarta. Selain menerjemahkan, Lahmuddin membuka pengajian kitab kuning dan membahas pembahasan tauhid, fiqh, dan tasawuf.

Ulama ketujuh adalah Ramli Abdul Wahid yang merupakan Ketua Dewan Fatwa Al Washliyah periode 2015-2020. Meskipun dikukuhkan sebagai Profesor dalam bidang Hadīth, ia tidak abai terhadap bidang-bidang keislaman lainnya. Buktinya, ia menulis karya-karya dalam bidang fiqh, 'ulūm al-Qur'ān, sejarah, teologi, terutama bidang hạaīth sebagai keahlian utamanya. Meskipun tidak murni kajian tauhid, karyanya dalam bahasa Indonesia yang berjudul Kupas Tuntas Ajaran Abmadiyah berisikan kritiknya terhadap doktrin aliran Ahmadiyah yang dinilainya sesat dan menyesatkan. Keunggulan buku ini adalah bahwa karya-karya Mirza Ghulam Ahmad dijadikan sebagai sumber acuan utama, selain karya-karya para tokoh Ahmadiyah. Buku ini diterbitkan pertama kali oleh LP2IK Medan, lalu dicetak ulang oleh Perdana Publishing Medan. Buku ini ditulis sebanyak 147 halaman dalam 
bahasa Indonesia. Ramli juga mengajarkan kitab Fath al-Majìd secara non-formal di perpustakaan miliknya di Sampali, Deli Serdang. Di Pendidikan Kader Ulama MUI Sumatera Utara, Ramli yang juga menjabat sebagai Ketua Komisi Fatwa MUI Sumatera Utara ini juga mengajar kitab Sharh al-'Alämat al-Kafrāiñ 'alā Matn al-Äjurümīyah karya Shaykh Hasan al-Kafrāwī.

Tabel 1:

Karya-karya Ulama Al Washliyah dalam Bidang Tauhid

\begin{tabular}{|c|c|c|c|}
\hline No. & Nama Ulama & Karya yang Dihasilkan & Bahasa \\
\hline 1 & $\begin{array}{l}\text { M. Arsjad } \\
\text { Thalib Lubis }\end{array}$ & $\begin{array}{l}\text { Pelajaran Iman } \\
\text { Al-'Aqä’id Al-İmānìyah li al- } \\
\text { Talämïdh li al-Dars al-Ibtidä'ỹyah } \\
\text { Bena-Bena Kepertjajaen Ibagessen } \\
\text { Agama Islam } \\
\text { Dasaring Kapertiajan Ing Agama } \\
\text { Islam }\end{array}$ & $\begin{array}{l}\text { Arab- } \\
\text { Melayu } \\
\text { Arab } \\
\text { Bahasa } \\
\text { Daerah } \\
\text { Bahasa } \\
\text { Daerah }\end{array}$ \\
\hline 2 & $\begin{array}{l}\text { M. Husein } \\
\text { Abd. Karim }\end{array}$ & Kifäyat al-Mubtadi' fì 'Tlm al-Kaläm & Arab \\
\hline 3 & $\begin{array}{l}\text { Nukman } \\
\text { Sulaiman }\end{array}$ & $\begin{array}{l}\text { Aqidah Islamiyah: Pokok-Pokok } \\
\text { Kepercayaan Dalam Islam }\end{array}$ & Indonesia \\
\hline 4 & $\begin{array}{l}\text { Abd. Majid } \\
\text { Siradj }\end{array}$ & Ikhtisär Ilm al-Tawhid & Arab \\
\hline 5 & $\begin{array}{l}\text { Hamdan } \\
\text { Abbas }\end{array}$ & Perkembangan Aqidah dalam Islam & Indonesia \\
\hline 6 & Rasyad Yahya & Ilmu Taubid & $\begin{array}{l}\text { Arab } \\
\text { Melayu }\end{array}$ \\
\hline 7 & $\begin{array}{l}\text { Lahmuddin } \\
\text { Nasution } \\
\text { (Penerjemah) }\end{array}$ & $\begin{array}{l}\text { Sharb Umm al-Barähin (Membahas } \\
\text { Sifat Allah yang Dua Pulub) }\end{array}$ & Indonesia \\
\hline 8 & $\begin{array}{l}\text { Ramli Abdul } \\
\text { Wahid }\end{array}$ & Kupas Tuntas Ajaran Ahmadiyah & Indonesia \\
\hline
\end{tabular}

\section{Peran Lembaga Pendidikan dalam Penyebaran Mazhab}

Al Washliyah mengembangkan mazhab Abl al-Sunnah wa alJama'a $a b$ dengan memberdayakan potensi amal usahanya, terutama bidang pendidikan. Beberapa tahun setelah berdiri, Al Washliyah telah mengelola sejumlah madrasah. Sebelum pemberlakuan SKB Tiga Menteri, madrasah-madrasah Al Washliyah menggunakan kitab kuning sebagai sumber pembelajaran, termasuk karya-karya dalam bahasa Jawi (Arab-Melayu). Sebagai organisasi yang menganut mazhab Shāfíīyah dan Abl al-Sunnah wa al-Jamāáah, Al 
Washliyah menggunakan karya-karya karangan ulama kedua mazhab ini. Untuk dapat memahami kitab kuning, madrasahmadrasah Al Washliyah mengajarkan bahasa Arab sebagai ilmu alat. Dari kurikulumnya, bisa diketahui bahwa madrasah-madrasah Al Washliyahmengajarkan kitab-kitab dalam mazhab Ash‘̄āìyah. Di tingkat Madrasah Tajhiziyah, diajarkan kitab Pelajaran Iman karya M. Arsjad Thalib Lubis. Kitab ini berbahasa Arab-Melayu, dan digunakan di tingkat dasar karena para pelajar masih belajar aksara Arab dan Arab-Melayu.

Di tingkat Madrasah Ibtidaiyah, diajarkan kitab Kifäyat al-'Awām fì Tlm al-Kalām karya Shaykh Muḥammad Fuḍāī, atau al-'Aqā’id alImānīyah li al-Talämìdh li al-Dars al-Ibtidā'ỹyah karya M. Arsjad Thalib Lubis. Kitab pertama berbahasa Arab, dan dipakai di tingkat Ibtidaiyah sebelum pemberlakuan SKB 3 Menteri. Penggunaan kitab berbahasa Arab di tingkat ini menunjukkan bahwa para pelajar setingkat Sekolah Dasar (SD) ini sudah mulai memahami bahasa Arab. Pada masa sekarang, madrasah-madrasah $\mathrm{Al}$ Washliyah tidak lagi menggunakan kitab Kifāyat al-'Awām di tingkat Ibtidaiyah, dan digantikan dengan kitab al-'Aqāid al-İmānìyah karya Arsjad yang merupakan pendiri Al wașliyah. Kitab ini memang berbahasa Arab, tetapi subtansinya lebih sederhana dan mudah dipahami. Kitab Kifāyat al-'Awàm memang dijadikan rujukan banyak lembaga pendidikan Islam di Indonesia. Penulisnya merupakan ulama al-Azhar, Kairo yang bermazhab Shāfíī dalam bidang fiqh, dan Abl al-Sunnah wa al-Jamäah dalam bidang akidah.

Di tingkat Madrasah Tsanawiyah, pelajar Al Washliyah diajarkan al-Husūn al- Hamidìyah li Muhäfazăt al-'Aqìdah al-Islämīyah karya Sayyid Husayn Afandi al-Jisr al-Ṭarābulusī. Kitab ini sudah digunakan sejak sebelum kemerdekaan, dan masih terus digunakan di tingkat Tsanawiyah sampai saat ini. Kitab ini berbahasa Arab, dan berisikan masalah Allah dan Rasul-Nya. Buku ini ditulis semasa pemerintahan Turki 'Uthmānī.

Di tingkat atas, Al Washliyah mendirikan Madrasah Qismul 'Aly sebelum era kemerdekaan. Madrasah jenis ini banyak melahirkan ulama-ulama Al Washliyah dan kurikulumnya berbasis kitab kuning. Dalam bidang tauhid, pelajar Al Washliyahdiajarkan kitab Hāshiyah al-Dasūqi 'alā Umm al-Barāhìn karya Shaykh Muḥammad b. Aḥmad b. 'Arafah al-Dasūqī al-Mālikī. Namun, kitab ini tidak bertahan lama dipakai di lembaga pendidikan ini dan 
digantikan dengan kitab Häshiyat Sharqāwì 'alā Sharh al-Hudhudì 'alā Umm al-Barāhin karya 'Abd Allāh al-Sharqāwī. Beberapa sebab di antaranya adalah tidak ada lagi guru yang bisa mengajarkan Häshiyat al-Dasūqĩ. Di antara persoalan yang dihadapi Al Washliyah pada saat ini adalah mulai langkanya keberadaan ulama yang berafiliasi dengan organisasi ini.

Pada tingkat pendidikan tinggi, Al Washliyah memiliki beberapa kampus, di antaranya Universitas Al Washliyah (UNIVA) di Medan. Dahulu, kampus ini memiliki Fakultas Ushuluddin yang akhirnya dileburkan menjadi Fakultas Agama Islam. Fakultas ini memiliki jurusan Pendidikan Agama Islam (PAI) Khusus yang sengaja dibuka untuk melestarikan tradisi kitab kuning dan misinya adalah untuk menyiapkan ulama Al Washliyah di masa depan. Jurusan ini mengajarkan ilmu-ilmu ke-Islaman dengan menjadikan kitab kuning sebagai sumber bacaan mahasiswa. Dalam bidang tauhid, jurusan ini memakai kitab Sharḅ 'Aqidat al-Tahạmìah karya al-Qāḍi 'Alī b. 'Alī b. Muḥammad b. Abī al-'Izz al-Dimshaqī (w. 1390) sebagai buku teksnya. Penulisnya merupakan ulama mazhab Hanafi asal Damaskus, Syria. Kitab ini merupakan syarah terpopuler atas kitab al-Aqidah al-Tahạmiyah karya Abū Ja'far alṬahāwī. Kitab tersebut berisikan 105 pokok keyakinan dalam mazhab Abl al-Sunnah wa al-jamäah dan diakui sebagai kitab terkemuka dalam mazhab ini. Selain itu, jurusan ini mengajarkan kitab Tafsì min Ayāt al-Ạ̣keàm min al-Qur'ān karya Muhammad 'Alī al-Ṣabūnī, Häshiyat al-Shaykh Ibrähìm al-Baijūì 'alā Fath al-Qarīb Sharh Matn Ghāyah wa al-Taqrīb karya Shaykh Ibrāhīm b. Muhammad b. Aḥmad al-Shāfí̄ì al-Baijūrī, Ibānat al-Aḥkām Sharh Bulügh al-Marām karya Ibn Hajar al-'Asqalānī, dan Haqāiq 'an alTasawnū karya 'Abd al-Qādir 'Īsā.

Tabel 2:

Kitab-kitab Tauhid di Madrasah Al Washliyah

\begin{tabular}{|c|c|c|}
\hline No. & Tingkat Madrasah & Kitab \\
\hline 1 & $\begin{array}{l}\text { Madrasah } \\
\text { Tajhiziyah/MDTA }\end{array}$ & $\begin{array}{l}\text { Pelajaran Iman karya M. Arsjad Thalib } \\
\text { Lubis }\end{array}$ \\
\hline 2 & Madrasah Ibtidaiyah & 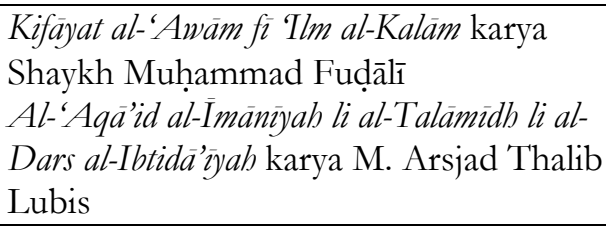 \\
\hline
\end{tabular}




\begin{tabular}{|c|c|c|}
\hline 3 & $\begin{array}{l}\text { Madrasah } \\
\text { Tsanawiyah }\end{array}$ & $\begin{array}{l}\text { al-Hushūn al-Hamidìyah li Muhäfazat al- } \\
\text { 'Aqüdah al-Islämīyah karya Sayyid H \{usayn } \\
\text { Afandi al-Jisr al-Ṭarābulusī }\end{array}$ \\
\hline 4 & $\begin{array}{l}\text { Madrasah al-Qismul } \\
\text { 'Aly }\end{array}$ & $\begin{array}{l}\text { Hāshiyat al-Dasūqì 'alā Umm al-Barāhìn } \\
\text { karya Shaykh Muhammad b. Ahmad b. } \\
\text { 'Arafah al-Dasūqì al-Mālikī } \\
\text { Hāshiyat Sharqāwì 'alà Sharh al-Hudihudì } \\
\text { 'alā Umm al-Barāhìn karya 'Abd Allāh al- } \\
\text { Sharqāwì }\end{array}$ \\
\hline 5 & $\begin{array}{l}\text { PAI Khusus FAI } \\
\text { UNIVA Medan }\end{array}$ & $\begin{array}{l}\text { Sharḅ 'Aqìdah al-Ṭahāwìyah karya al-Qādīi } \\
\text { 'Alī b. 'Alī b. Muhammad b. Abī al-'Tzz } \\
\text { al-Dimashqī }\end{array}$ \\
\hline
\end{tabular}

Secara non-formal, kajian tauhid diadakan di rumah ulama $\mathrm{Al}$ Washliyah atau masjid kampus UNIVA Medan. Di antaranya pengajian di rumah Ramli Abdul Wahid yang merupakan Ketua Dewan Fatwa Al Washliyahperiode 2015-2020. Dalam bidang tauhid, pengajian ini mengulas kitab Fath al-Majid karya Shaykh Muhammad Nawawī al-Jāwī al-Bantan̄i. Kitab ini merupakan penjelasan terhadap kitab Durr al-Farid fí 'Aqä'id Abl Tawhid karya Shaykh Aḥmad al-Nahrāwī. Shaykh Nawawī al-Bantanī merupakan ulama yang berkiprah di Masjid al-Ḥarām, Mekah, tetapi berasal dari Banten, Indonesia, yang ahli dalam bidang tauhid, fiqh, tafsir, hadìth, dan tasawuf. Selain itu, pengajian ini juga membahas kitab Sharb al-Hikam dalam bidang tasawuf, kitab Fath al-Mu'n dalam bidang fiqh, dan kitab Matn al-Arbain al-Nawawiyah dalam bidang hadīth. Pengajian ini diadakan setiap hari Sabtu di perpustakaan milik Ramli yang terletak di Sampali, Deli Serdang. Selain itu, OK Mas'ud yang merupakan ulama Al Washliyah juga mengadakan kegiatan serupa di rumahnya, di mana ia mengulas sejumlah kitab kuning, khususnya kitab Fath al-Majid karya Shaykh al-Nawawī alBantanī.

Selain itu, kampus UNIVA Medan juga memiliki sebuah masjid yang biasa digunakan untuk pengajian kitab kuning. Kegiatan ini diadakan di setiap hari Minggu dan membahas beberapa kitab kuning dalam bidang tauhid, fikih dan tasawuf. Dalam bidang tauhid, dibahas kitab Sharh al-Baijūi 'alà Jawhar al-Tawhid, dan Lahmuddin Nasution yang merupakan pengurus teras Dewan Fatwa Al Washliyah menjadi pengulas kitab. Pengajian ini juga mengulas kitab al-Muhadhdhab fì Fiqh al-Imām al-Shäfí kà karya Abū 
Ishāq al-Shīrāzi dalam bidang fiqh dan Sharh al-Hikam karya Ibn Ața'illāh al-Sakandarī dalam bidang tasawuf. Kajian kitab Sharh alHikam juga diadakan di rumah Prof. Aslim Sihotang di Medan dan menempatkan Lahmuddin sebagai figur sentral dalam pengajian tersebut. Selain itu, Syarbaini Tanjung, pengurus Dewan Fatwa Al Washliyah periode 2015-2020 mengajarkan kitab Tuhfat al-Murid Sharh Jawhar al-Tawh\} ìd karya Shaykh Burhān al-Dīn Ibrāhīm b. Hasan al-Laqqānī di Pendidikan Kader Ulama yang keberadaannya diinisiasi oleh Majelis Ulama Indonesia (MUI) Sumatera Utara.

Tabel 3:

Kitab-kitab Tauhid di Pengajian Kitab Kuning

\begin{tabular}{|c|c|c|}
\hline No. & Nama Kitab & Karya \\
\hline 1 & Fath al-Majìd & $\begin{array}{l}\text { Shaykh Muhạmmad Nawawī } \\
\text { al-Bantanī }\end{array}$ \\
\hline 2 & $\begin{array}{l}\text { Sharh al-Baijürì 'alä Jawhar al- } \\
\text { Tawhy id }\end{array}$ & Shaykh Ibrāhīm Baijūrī \\
\hline 3 & $\begin{array}{l}\text { Tubfat al-Murid Sharb Jawhar } \\
\text { al-Tawhy id }\end{array}$ & $\begin{array}{l}\text { Shaykh Burhān al-Dīn } \\
\text { Ibrāhīm b. Hasan al-Laqqānī }\end{array}$ \\
\hline
\end{tabular}

Pada saat ini, pengajian kitab kuning kurang gencar diadakan Al Washliyah secara non-formal, kecuali di madrasah-madrasah yang dikelola sejak lama khususnya Madrasah Muallimin Al Washliyah yang berada di kompleks UNIVA Medan, dan Madrasah al-Qismul 'Aly Al Washliyah sebanyak empat unit di Sumatera Utara (di Kota Medan sebanyak satu unit, di Perbaungan Kabupaten Serdangbedagai sebanyak satu unit, di Kedaisianam Kabupaten Batu Bara sebanyak satu unit, dan di Tanjungtiram Kabupaten Batu Bara sebanyak satu unit). Beberapa Madrasah alQismul 'Aly telah tutup misalnya yang berada di Lubukpakam, Deli Serdang. Penyebabnya adalah para pelajar saat ini kurang meminati madrasah yang memang khusus menyiapkan ulama seperti ini, kebijakan pemerintah terhadap kurikulum madrasah, keterbatasan guru yang mampu mengajarkan kitab kuning yang pelik substansinya, dan kurangnya perhatian pengurus Al Washliyah terhadap masa depan Madrasah al-Qismul 'Aly. Tentu saja, pengurus Al Washliyah menjadi pihak yang bertanggungjawab terhadap kemunduran madrasah tersebut, yang akhirnya berimplikasi terhadap kelangkaan ulama dalam artian yang sesungguhnya dalam organisasi Al Washliyah. 
Al Washliyah memiliki 'segudang' dan dai yang juga guru dan dosen di lembaga pendidikan Al Wașliyah, tidak saja di Sumatera Utara yang saat ini masih menjadi basis amal usaha dan konstituen organisasi, tetapi juga di luar Sumatera Utara terutama seperti Aceh, Riau, Jawa Barat, dan Kalimantan Selatan. Hanya saja, sebagian mereka bukan merupakan kader tulen organisasi dalam arti yang sesungguhnya, melainkan alumni madrasah dan perguruan tinggi Al Washliyah yang telah dianggap sebagai kader organisasi meskipun penggunaan istilah kader bagi alumni lembaga pendidikan organisasi ini agak janggal dan terlalu longgar bahkan multitafsir. Kasus serupa bahkan melanda pengurus organisasi dari tingkat ranting sampai Pengurus Besar, sebab banyak di antara mereka bukan kader organisasi (dalam arti mengikuti jenjang pengkaderan IPA maupun pengkaderan HIMMAH yang keduanya memang dikenal sebagai lumbung kader dalam organisasi $\mathrm{Al}$ Washliyah). Keadaan ini diperparah oleh adanya aktivitas "mengalwashliyahkan" orang-orang yang berpengaruh dari kalangan pengusaha dan politisi, padahal keberadaan mereka belum tentu bermanfaat bagi masa depan organisasi. Artinya, kelangkaan ulama diikuti oleh kelangkaan pengurus yang berasal dari kader organisasi. Tetapi tidak bisa diabaikan bahwa guru dan da'i berperan bagi pelestarian mazhab Abl al-Sunnah wa al-Jamäah di Indonesia.

\section{Penutup}

Studi ini menunjukkan bahwa Al Washliyah merupakan organisasi sosial keagamaan yang berasas Islam dengan menganut mazhab Shāfíī dan Abl al-Sunnah wa al-Jamāáah. Dari awal berdiri di era kolonial Belanda sampai saat ini, tidak ada perubahan asas dalam organisasi ini, sembari menunjukkan kesetiaan konstituennya terhadap kedua mazhab tersebut. Pemilihan mazhab Shāfíī dan Abl al-Sunnah wa al-Jamāáab tidak bisa dilepas dari mazhab yang dianut para pendiri Al Washliyah dan guru-guru mereka di Sumatera Timur maupun di Haramayn (Mekah dan Madinah). Dari aspek silsilah, sanad keilmuan ulama dan pendiri Al Washliyah terhubung sampai kepada ulama pendiri mazhab Ash'ārī yang menjadi tulang punggung mazhab Abl al-Sunnah wa al-Jamāáah. Ulama-ulama Al Washliyah juga menulis karya dalam bidang tauhid. Karya-karya mereka menjadi sumber bacaan bagi pelajar dan mahasiswa Al Washliyah. Dalam rangka menyebarkan dan 
melestarikan mazhab Abl al-Sunnah wa al-Jamäah, Al Washliyah memanfaatkan lembaga-lembaga pendidikan yang dikelolanya, terutama madrasah-madrasah dan jurusan keagamaan yang ada di kampus milik organisasi. Beberapa ulama membuka kajian kitab kuning dan menempatkan kitab-kitab dalam mazhab Ash'ārīyah sebagai referensi utama dalam pengajian yang mereka buka. Keberadaan Al Washliyah sebagai organisasi Islam berperan dalam memperkuat akidah Sunnī di Indonesia, dan ulama-ulamanya menjadi pengawal akidah umat dari pengaruh paham dan aliran sesat yang muncul. Sejak awal, Al Washliyah menolak paham dan keberadaan Ahmadiyah di Indonesia. Terkait Shi'‘ah, Dewan Fatwa Al Washliyah pernah menyatakan bahwa Shī'ah bukan aliran sesat, tetapi mayoritas ulama organisasi ini menolak paham dan aliran Shī'ah yang muncul dan berkembang di Indonesia. Studi ini membuktikan bahwa Al Washliyah dan para ulamanya turut melestarikan akidah Sunnī dan mengawal akidah umat.

\section{Daftar Rujukan}

Al Rasyidin. "Organisasi Islam di Tanah Melayu: Ideologi dan Gerakan Al-Ittihadiyah sebelum Era Reformasi", Journal of Contemporary Islam and Muslim Societies, Vol. 2, No. 1, 2018.

Anonim. "Orang Kristen Tidak Benar Pertjaja Kepada Nabi Isa", Medan Islam, Vol. 2, No. 9.

Azra, Azyumardi. "Muhammadiyah: A Preliminary Study", Studia Islamika, Vol. 1, No. 2, 1994.

Bruinessen, Martin van. NU: Tradisi, Relasi-relasi Kuasa, Pencarian Wacana Baru. Yogyakarta: LKiS, 1994.

Butar-butar, Arwin Juli Rakhmadi. "Kajian Ilmu Falak di Indonesia: Kontribusi Syaikh Hasan Maksum dalam Bidang Ilmu Falak", Journal of Contemporary Islam and Muslim Societies, Vol. 1, No. 1, 2017.

Hasanuddin, Chalidjah. Al Jam'iyatul Washliyah 1930-1942: Api dalam Sekam di Sumatera Timur. Bandung: Pustaka, 1988.

Ilyas, Ahmad Fauzi. "Shaykh Ahmad Khatib Minangkabau dan Polemik Tarekat Naqsyabandiyah di Nusantara", Journal of Contemporary Islam and Muslim Societies, Vol. 1, No. 1, 2017. Ja'far dan Irwansyah (eds.). Anak Desa Tak Bertuan Jadi Profesor: Kisah Nyata Kehidupan 60 Tahun Prof. Dr. Drs. Ramli Abdul Wabid, Lc., MA. Medan: Manhaji, 2016. 
"Peran Al Jam'iyatul Washliyah dalam Merevitalisasi Mazhab Shafi'i di Era Kontemporer", Justicia Islamica: Jurnal Kajian Hukum dan Sosial, Vol. 13, No. 1, 2016.

. "Respons Dewan Fatwa Al Jam'iyatul Washliyah terhadap

Isu Akidah dan Syariah di Era Global", al-Manabij: Jurnal Kajian

Hukum Islam, Vol. 10, No. 1, 2016.

"Tarekat dan Gerakan Sosial Shaykh Hasan Maksum",

Teosofi: Jurnal Tasawnf dan Pemikiran Islam, Vol. 5, No. 2, 2015.

- Biografi Ketua Umum Pengurus Besar Al Jam'iyatul Washliyah

1930-2015. Medan: Perdana Publishing, 2015.

- Dari Tanah Deli Untuk. Negeri: Historisitas, Religiusitas dan

Nasionalisme Gerakan Pemuda Al Washliyah. Yogyakarta: KMedia, 2019.

. Ikatan Pelajar Al Waṣliyah: Gerakan, Identitas dan Ideologi

Pelajar Muslim di Nusantara 1953-2017. Medan: Perdana Publishing, 2018.

Tradisi Intelektual Al Washliyah: Biografi Ulama Kharismatik. dan Tradisi Keulamaan. Medan: Perdana Publishing, 2015.

Jamil, M. dan Ja'far. "Pemimpin Perempuan dan Non-Muslim

Perspektif Ulama Tiga Serangkai", TEOSOFI: Jurnal Tasawnf dan Pemikiran Islam, Vol. 8, No. 1, 2018.

Koto, Alaiddin. Persatuan Tarbiyah Islamiyah: Sejarah, Paham

Keagamaan dan Pemikiran Politik 1945-1970. Jakarta: Rajawali Press, 2012.

Lubis, M. Arsjad Th. "Penjiaran Islam Al Dj. Washlijah", dalam M. Husein Abd. Karim. 21 Al Dj. Washlijah. Medan: Pustaka Al Washlijah, 1951.

Noer, Deliar. Gerakan Modern Islam di Indonesia 1900-1942. Jakarta: LP3ES, 1980.

Nurdin, Mhd. "Riwajat Ringkas dan Pendjelasan Madjlis Anak Miskin dan Jatim Pijatu Al Djamijatul Washlijah", dalam M. Husein Abd. Karim. 21 Al Dj. Washlijah. Medan: Pustaka Al Washlijah, 1951.

Pengurus Besar Al Djam'ijatul Washlijah. Putusan-putusan Kongres Al Dj. Washlijah ke-XI Tanggal 27 s/d 30 Nopember 1959 di Medan. Medan: Pengurus Besar Al Djamijatul Washlijah, 1959.

Pengurus Besar Al Djamijatul Washlijah. "Anggaran Dasar dan Anggaran Rumah Tangga", dalam Putusan-putusan Muktamar Al 
Dj. Washlijah ke-XII Tanggal 30 Nop. s/d 4 Desember 1962 di Langsa. Medan: Pengurus Besar Al Djamijatul Washlijah, 1962. Pimpinan Pusat Gerakan Pemuda Al Washlijah. "Anggaran Dasar

Gerakan Pemuda Al Washlijah", dalam Nukman Sulaiman (ed.). Peringatan Al Djamijatul Washlijah 1/4 Abad. Medan: Pengurus Besar Al Djamijatul Washlijah, 1956.

Pimpinan Pusat Puteri Al Washlijah. "Anggaran Dasar Puteri Al

Washlijah", dalam Nukman Sulaiman (ed.). Peringatan Al

Djamijatul Washlijah 1/4 Abad. Medan: Pengurus Besar Al Djamijatul Washlijah, 1956.

Qa'im, Suis. "Genealogi Teologi Nahdlatul Ulama", ISLAMICA:

Jurnal Studi Keislaman, Vol. 6, No. 2, 2012.

Riza, Achmad Kemal. "Contemporary Fatawa of Nahdlatul Ulama:

Between Observing the Mazhab and Adapting the Context", Journal of Indonesian Islam, Vol. 5, No. 1, 2011.

Siddik, Dja'far dan Ja'far. Al Ittihadiyah: Delapan Dasawarsa Menerangi Nusantara. Medan: Perdana Publishing, 2017.

Silvita, Mary. "Presiden Non-Muslim dalam Komunitas Masyarakat Muslim", ISLAMICA: Jurnal Studi Keislaman, Vol. 7, No. 1, 2012.

Sjamsuddin, Udin. "Tjatetan Ringkas dari Sedjarah Perkembangan Organisasi Al Djam. Washlijah", dalam M. Husein Abd. Karim. 21 Al Dj. Washlijah. Medan: Pustaka Al Washlijah, 1951.

Sjamsuddin, Udin. Chutbah Pengurus Besar Memperingati Ulang Tahun Al Djamijatul Washlijah Seperempat Abad: 30 November 1930-30 November 1955. Medan: Pengurus Besar Al Djamijatul Washlijah, 1955.

Sjihab, Abdurrahman. "Memperingati Al Djam'ijatul Washlijah 21 Tahun 30 November 1930-30 November 1951", dalam M. Husein Abd. Karim. 21 Al Dj. Washlijah. Medan: Pustaka Al Washlijah, 1951.

Suharto, Toto. "Gagasan Pendidikan Muhammadiyah dan NU Sebagai Potret Pendidikan Islam Moderat di Indonesia", ISLAMICA: Jurnal Studi Keislaman, No. 9, No. 1, 2014.

Tanjung, Muaz. Maktab Islamiyah Tapanuli 1918-1942: Menelusuri Sejarah Pendidikan Islam Awal Abad ke-20 di Medan. Medan: IAIN Press, 2012. 
Wahid, Ramli Abdul. "Akidah Al Waṣliyah", http://kabarwașliyah.com, 21 Januari 2014.

Yunus, Mahmud. Sejarah Pendidikan Islam di Indonesia. Jakarta: Hidakarya Agung, 1993.

Zuhri, Achmad Muhibin. "Particular Sunnism Versi Hasyim Asyari tentang Ahl al-Sunnah wa al-Jamāah", ISLAMICA: Jurnal Studi Keislaman, Vol. 5, No. 2, 2011. 